\title{
Development of Successful Resort Design with Vernacular Style in Langkawi, Malaysia
}

\author{
Ahmad Sanusi Hassan (Corresponding author) \\ School of Housing, Building and Planning \\ Universiti Sains Malaysia, Penang, Malaysia \\ Tel: 60-4-653-2835 E-mail: sanusi@usm.my \\ Aymen Emalgalfta \\ Department of Engineering, University of Misurata \\ Misurata, Libya \\ E-mail: elmagalfta@yahoo.com \\ $\mathrm{Ku}$ Azhar Ku Hassan \\ School of Housing, Building and Planning \\ Universiti Sains Malaysia, Penang, Malaysia \\ E-mail: kuazhar@usm.my
}

\begin{abstract}
This paper discusses resort design with an adoption of vernacular style in Langkawi, Malaysia. Resort refers to building or a group of buildings designed in a particular setting to cater for both relax and recreational activities. The resort sites may front beaches, lagoons, hill slopes or lakes or provide elevated views with convenient access to the waterfront activities. Vernacular style becomes increasingly popular for the design of resort hotels. Langkawi Island since 1990 has been gazetted as the national tourist's destination due to its pristine beaches, scenic beauty, richness of cultural heritage and preserved tropical environments. The resort development shows that Langkawi has a potential as an attractive tourist destination from around the world. Three vernacular resorts are selected for the case study based on their different designs and locations, which are Berjaya Langkawi Beach and Spa Resort (modern vernacular style), Pelangi Beach Resort (post modern vernacular style) and Kampung Tok Senik Resort (old traditional vernacular style). The study finds that Kampung Tok Senik Resort is the best design for vernacular style's resort. This study is also able to indicate several critical factors in the analysis for improvement of the resort design in the future.
\end{abstract}

Keywords: Resort, Vernacular style, Tropical design, Langkawi

\section{Introduction}

Vernacular style lately becomes a popular character used by the architects for the resort design. Traditional design becomes the model for resort hotels. In tourism industry, a past culture has an overpowering effect on design as a symbol of the cultural heritage (Hassan, 2000), and traditional values in considering ecological architecture (Steele, 2005). The objective is to attract as many tourists as possible to the country. This paper focuses on the study of successful luxurious resort design with adaptations of vernacular style in Langkawi, Malaysia. The study is divided into two categories which are literature review and survey. The literature review consists of the study of resort buildings (in general) and vernacular resort buildings in Malaysia. The purpose is to search for critical factors which can be used for questionnaires of the survey. The survey is based on comparisons of three vernacular resort buildings in Langkawi, which have three different designs and are located at three different locations. The result of the survey will become the indicators to the level of success of the resort designs. 


\section{Resort Buildings}

Resort is a place where people often go, customarily or generally, for rest or recreation as on holiday. With changes due to development in air transport, this gives access to the tourists from all over the world to stay at resorts located at more distant areas like in Langkawi (Tourism Malaysia, 2000) which offer better and more preferable climates, new and exciting natural surroundings, more attractive cultural experience, and better equipped facilities (Baud-Bovy and Lawson, 1998). According to Huffadine (1999), resort may be simply defined as an accommodation facility that is related with recreational activities. This implies places to make social contacts attend social occasions and improve health and fitness. Resorts make the environment more beautiful and add amenities to attract customers. The differences between a resort and a conventional hotel can be described in terms of the guest purpose in staying at the facility. The guest at resort does visits for relaxation or recreation in contrast to the guest who stay at the conventional hotel.

\section{Langkawi and Some Luxurious Resort Buildings}

Langkawi has been planned by the government of Malaysia since 1990's to be one of the most popular tourist destination in Southeast Asia with the status of popularity similar to Bali island, Thailand and Phuket Island, Indonesia (Emalgalfta, Hassan \& Ku Hassan, 2009). Many investments have been made by local and multinational companies leading to the construction of luxurious resort projects in Langkawi. The development shows that Langkawi has a potential as an attractive tourist destination from around the world. Many factors contribute to this phenomena, such as the abundance of naturally beautiful sceneries, the vernacular houses and kampungs, the rivers and mountains, the tropical rainforests and mangroves, the natural lakes, the sandy beautiful beaches, the crystal clear sea and coral reefs coupled with the diverse historical and cultural heritage (Tourism Malaysia, 2000). Resort settings is at areas which are associated with establishing profitable and ecologically sustainable industry, while simultaneously achieving a safe and satisfying experience for the visitors and raising standards of living to the local community. According to Tan (2001), World Travel and Tourism Council predict that the Asia-Pacific region will contribute about $25 \%$ of the world's travel market. Tourism in Malaysia, especially after 1990, is expected to be popular and most of the developments will be focused on traditional resorts (Mohamed, 2002). According to Hassan (1998), the vernacular design will become the popular style for resort buildings as well as commercial hotels.

Langkawi island becomes a major attraction in tourism industry in Malaysia. The island is gazetted as the national destination of tourism place due to its pristine beaches, scenic beauty, richness of cultural heritage and preserved tropical environments (Figure 1, $2 \& 3$ ). The resort tends to be built in environmentally sensitive areas such as seaside, hill, lakeside or riverside. The island of Langkawi is under the state of Kedah. It is located at the north-western shore of Peninsular Malaysia. Langkawi comprises of 99 tropical islands, the main island is popularly known as Pulau Langkawi. Other popular islands are Singa Besar, Dayang Bunting and Burau islands. As a natural paradise for tourism destination, the islands are unmatched anywhere else in Southeast Asia. It makes Langkawi the ideal choice as a holiday or business-holiday destination. Modern amenities and infrastructure boasted in Langkawi today while the island itself is able to sustain its traditional values. Many places of interest with natural attraction are found in Langkawi such as pristine beaches at Cenang beach, freshwater lake at Dayang Bunting island, Seven Wells waterfall and scenic views from Mat Chincang Mount (Figure 1). Most luxurious resorts are built around the beaches at (i) Cenang Beach, (ii) Datai Bay, (iii) Tengah Beach (iv) Tanjung Rhu Beach, (v) Kok Beach and Burau Bay, (vi) Kuah and (vii) hilly areas at the rural settings (central part of the island). Cenang beach is the most popular location for the resort hotels in Langkawi.

\section{Critical Factors for the Resort Design}

The critical factors for resort design at Langkawi can be divided into two categories which are design to fit with: A). Resort requirements and B). Regional style. The resort requirements consists of important considerations for selection of the resort location, interior and exterior chalet design based on resort style, appropriate facilities and services, building materials, and prices of accommodation. On the other hand, Regional style comprises important considerations for adequate ventilation for cooling and reduction of humidity (Kamaruddin, 1983), using low thermal building materials, avoiding direct sunlight and glare, protection against rain, and the site's location with natural vegetations to provide cooler micro climate. Based on these considerations, this study finds that there are six critical factors which are important in resort design as follows:

\subsection{Site Planning}

The hotel sites may front beaches, lagoons or lakes directly with waterfront activities (Lawson, 1995). A resort location is one, which is sufficiently appealing such that people will travel to it and stay at least one day and one night. Besides Schwanke, (1997) argued that resorts should offer proximity and easy access to significant, natural, scenic, recreational and cultural amenities. The resorts built with vernacular style are considered as attractive to the tourists (Tan, 2001) and in the case of Langkawi, is a profitable investment to the country's tourism industry. Appropriate signage and symbol are important as parts of the design to identify the resort hotel, provide information and serve directions to the visitors to 
the various facilities (Smith, 1978). At the same time, the graphic design must subtly suggest the status and character of the resort hotel (architectural design) in order to create and reinforce customer recognition, confidence and loyalty (Lawson, 1995). The labels of signage and graphic design especially the entrance signage must be consistent throughout the resort property. All the graphic symbols need to be coordinated with the character of the exterior and interior design of the buildings and chalets. This study finds that there are four important factors in this research survey as follows:
a). Location
b). Chalet reach ability
c). Entrance
d). Signage

\subsection{Exterior Design}

The Malay house is a house raised on stilts made of building materials such as hardwoods, softwoods, bamboo, tree roots and nypa leaves, (Gibbs, 1987) available from the tropical lowland forests and wetlands. Usually the house has a dominant roof, veranda or porch in front, high ceilings and large openings for ventilation purposes (Lim, 1984). The traditional Malay house is basically a post-and-lintel prefabricated timber structure with wooden or bamboo walls and a thatched nypa roof. Roof design plays important character to the resort image. Resort hotels usually have a design of vernacular style, which is appropriate architectural expression to cater for leisure travellers particularly during weekends and holiday periods (Emalgalfta, Hassan \& Ku Hassan, 2006). The purpose is to create an environment of the past for the tourists. Reverting to traditional values leads to profit making. Tourists are offered with cultural and traditional attractions, presenting the experience of the past, which is not available in other parts of the world (Tan, 1994). A range of traditional Malay roof forms (Figure 4) can be identified in Peninsular Malaysia with four different shapes which are Bumbung Panjang (Long Roof), Bumbung Limas (Limas Roof), Bumbung Perak (Perak Roof) and Bumbung Lima (Lima Roof). The hotel sites offer exceptional exterior view of the natural surrounding and man-made landscape settings from the verandahs (Emalgalfta, Hassan and Ku Hassan, 2006 \& Smith, 1978), and provide elevated views to the waterfront activities (Lawson, 1995). According to Schwanke (1997), most resort hotels are based on the leisure attractions of water both as recreational amenity and visual setting. Some resorts are also located at attractive hilly areas or rural setting for the guest to offer living experience at natural setting. Based on this literature review, there are five critical factors for the exterior design of resort building which are:
a). Building materials
b). Roof
c). Verandah
d). Exterior view
e). Landscape design

\subsection{Interior Design}

High-quality durable fitments and finishes are also important in order to ensure easy maintenance services. The choice should reflect to vernacular style with traditional craftsmanship (Tan, 1994). Furniture and furnishings in hotel are subject to more intensive use, strain and damage than domestic units. Decoration and furnishing as proposed by Lawson (1995) need to fit with traditional and resort style, and are durable (resistant to damage and discolouring) and low maintenance services (easy cleaning and replacement of the parts). Room (chalet layout) accommodations in resort hotels are often carefully positioned with an attractive setting (Emalgalfta, Hassan and Ku Hassan, 2006). The Malay house layout becomes an important reference to the chalet. It has basically the front and back portions which are centred around Rumah Ibu (core house) with Dapur (kitchen). From the entrance, stairs lead up to a covered porch or verandah called Anjung. The porch acts as a good transition space between the public and the private domains. According to Khan (1981), Gibbs (1987), Nasir and Wan Teh (1997), the main factor which typifies the Malay house is its concept of open layout. Often the house has only one room, apart from the separation between Rumah Ibu (the core house) and Dapur (kitchen). The house has spaces that are assigned specific functions by their location (Figure 5) such as (i) Anjung (porch/ front verandah), (ii) Serambi Gantung (corridor verandah), (iii) Rumah Ibu (core house), and (iv) Selang (passageway).

According to Lawson (1995), the room units (always in form of chalet unit) in holiday villages and resort complexes usually vary in style to create individuality and character. The density of building is disguised by landscape and the retention or interpolating of trees and scrubs (Smith, 1978) to separate and screen groups of the units. The study concludes that there are five critical factors which are important for the survey. These factors are as follows:

a). Interior view

b). Interior finishes 


\section{c). Chalet layout \\ d). Chalet size \\ e). Accessibility \\ 4.4 Passive and Active Design}

Vernacular style becomes increasingly popular styles for the design of resort hotels. The same situation applies to the case of the development of resort hotels in Peninsular Malaysia where styles of the Malay traditional houses are popularly adopted. According to Nasir and Wan Teh (1996), the traditional Malay house has satisfied the basic needs of the Malays adjusted to suit to the warm and humid climate. The form of the house was greatly influenced by the natural surroundings of the tropical climate and traditional socio-economies, which are paddy growing and fishery activities (Hassan and $\mathrm{Ku}$ Hassan, 2001). Vernacular resort design refers to buildings that use traditional style in its design.

The application of this style can be done in many ways such as the design of roof form, building facades, window openings and sun shading devices, the use of local materials and decorative elements. In many cases, traditional resorts are developed from existing villages and towns either by changing the town itself or growing in its immediate neighborhood (Baud-Bovy and Lawson, 1998). The roof is normally high with maximum window's openings, extensively use of louvers and large overhangs for ventilation and shading purposes (Lawson, 1995). Windows provide good ventilation and exterior views for the house. This openness concept is also reflected by large openings of the (Tan, 1994) spaces with minimal partitions. The study concludes that there are four critical factors which are important for the survey. These factors are as follows:
a). Ventilation
b). Shades/Natural lighting
c). Room's temperature
d). Artificial lighting

\subsection{Design of Facilities}

Resort hotels are often set within larger resort communities allowing them with convenient access to the waterfront activities (Lawson, 1995), and to offer access to a range of amenities included in the community, such as, jungle tracking, beach parks, amusement facilities and retail services (Schwanke, 1997). The hotel sites offer exceptional access to the natural surrounding and man-made landscape settings (Emalgalfta, Hassan and Ku Hassan, 2006). The resorts are always provided with restaurant services, an extensive lobby and comfortable sitting areas (Schwanke, 1997). The design of furniture, fitments and finishes need to fit with the local character (Lawson, 1995). Toilet and bathing facilities areas must include visual screening from public areas and a separately ventilated intervening space may be required for entry from a room (Lawson, 1995). The study concludes that there are four critical factors which are important for the survey. These factors are as follows:
a). Accessibility (facilities)
b). Room facilities (design)
c). Toilet facilities
d). Bathing facilities

\subsection{Price}

It becomes a crucial factor that can influence the success of resort design. The guests always look for the overall design in comparison to the price. According to Schwanke (1997) resort hotels are by far the most common types of resort property. The accommodation in these facilities ranges from very modest to rustic facilities, such as, tent cabin to luxury resort suites with all the comforts of home and more. In this survey, one question will be asked to the respondents about the price of accommodation in relation to the resort design.

\section{Case Study of the Resorts}

Three luxurious resort buildings in Langkawi are chosen for the case studies. All selected resort buildings have five star rating. All resorts are sensitively designed to suit the local conditions. Their selection is important, besides being designed in vernacular style, each resort is selected based on it's uniqueness in term of the styles and location (Figure 6). They are namely:

a) Berjaya Langkawi Beach and Spa Resort with simple vernacular style located at the hill slopes along rocky seaside at Burau Bay

b) Pelangi Beach Resort Langkawi with complex traditional style along flat sandy seaside at Cenang Beach

c) Kampung Tok Senik Resort with old vernacular style at the countryside's hilly area in Padang Masirat district. 


\subsection{Berjaya Langkawi Beach and Spa Resort (BBR)}

Berjaya Langkawi Beach and Spa Resort (BBR) has simple vernacular style's design. All the chalets are built on stilts several metres from the sea level and at the hill slopes along the beautiful Burau Bay (Figure 7). The owner of this resort is Berjaya Group, a multinational company. The chalet design has the simplified Malay house's architectural character, set amidst lush tropical rainforests whose buildings are individually designed to fit in harmony with their surroundings. The chalet design has less uses of decorative elements. It uses basic timber construction's concept with dominant roof form. Site location of the chalets is determined on site, not by the normal architect's drawings so that this is able to avoid unnecessary tree cuttings (site clearings). The combination of pre-cast concrete columns and timber frames and components is used in the construction. All chalets have a layout oriented a view to the sea. Open anjung type of veranda and corridor, raised platform, and single-story structure with minimum decoration and carving are the identical architectural features of this resort. The major architecture focus of the building is its prominent roof form which adopts the traditional 'Perak Roof Form' (Bumbung Perak) found extensively at the central region of the western coastal state in Peninsular Malaysia.

\subsection{Pelangi Beach Resort}

Pelangi Beach Resort, (the word 'Pelangi' means Rainbow in Malay Language), is located on the west coast on the western coast of Langkawi. The resort spreads over 30 acres of palm fringes beach front facing Pulau Rebak Kecil offers a luxurious resort lifestyle in a Malaysian village setting. Standing in extensive grounds on the beach, Pelangi Beach Resort (PBR) is located right on Pantai Cenang (Figure 8). Unlike typical traditional Malay house, this resort has two storey chalets. In contrast to the traditional Malay house form, the wooden chalets are raised on stilts less than one metre's high. Every room has an extended veranda and the upper rooms have high ceiling due to the height of the complex roof pitch. The chalets have complex vernacular style with tropical landscape such as existing coconut trees, playground, courtyard, pergolas, bridges, lakes, fountains, swimming pools, and waterfalls inside the resort complex, and natural sandy beach at its west. This resort offers a luxurious resort lifestyle in a Malaysian village setting. The main architecture focus of the building is its prominent complex roof form which is the combination of the traditional 'Long Roof Form' (Bumbung Panjang), 'Perak Roof Form' (Bumbung Perak) and anjung type of roof form. Characteristically raised on stilts, the chalets are identical with its complex sloping roof forms, exposed roof tiles and trusses, and a private serambi type veranda. The resort is designed to replicate traditional Malay house architecture with heavy dark wood colour.

\subsection{Kampung Tok Senik Resort}

Kampung Tok Senik Resort (KTSR) is located in a hilly area used to be before as rubber estate (Figure 9) at Padang Matsirat surrounded by a vast paddy field in central part of Langkawi. This resort has detached, semi-detached and terraced chalets built in old (rustic) traditional style with a backdrop of paddy fields. The idea is to imitate a picturesque landscape to the typical setting of the Malay villages and house form. According to Ku Hassan and Shuib (2000), the resort layout is dictated by the natural landform of the site. The houses are arranged like the layout of the Malay villages at random position and scattered around the sloping terrain. The chalets have extensive use of timbers, classic woodcarvings and a dominant thatched nypa long roof form that reflect the functionality and utilisation of the local materials used in the precolonial (architecture before colonial period) traditional house form. The chalet accommodation emulates the overall Malay theme with one storey wooden chalets. It has higher ceiling due to the shape of its roof pitch. The design and name of the houses reflect the hierarchy of the activities represented by the house identical with the name of the person who lives at the old Malay villages such as Rumah Penghulu (Leader House), Rumah Tok Imam (Imam House), Rumah Pawang (Traditional Doctor House) and Rumah Tok Dukun (Malay Medicine Man/Woman) to create the ambience of kampung's (village's) atmosphere. They are designed in the old vernacular style's vocabulary of various forms and configurations that are associated with Kedah House (houses at northern region state in Peninsular Malaysia).

\section{The Survey}

With respect to resort building, there is a growing tendency for the resort developer to propose the use of local traditional design features as the design theme or concept. This is natural, for it usually captures the attention of most tourists to the place. Through this approach, architects have the opportunity to reveal some beautiful and practical local design form, materials, construction techniques and crafts, and to execute both modern and efficient building design. However, one would easily ask, does this vernacular style really plays an important role in attracting customers to the resort? What are the design criteria that should be emphasised to the resort design? Based on the above assumptions, this paper sets to determine the success of the resort design by referring to the overall results of the survey which are based on the level of preference and satisfaction among the tourists who have stayed in these selected resort buildings.

The research, design and methodology with the intention to obtain validity in the research findings were developed. By conducting these types of the research methodology, the research seeks to answer the results of the entire research 
questions through analysis of the respondents' responses to the questionnaires. The result of the survey will be able to determine the success of the resort design which can be used as primary considerations for the future design guidelines and development in Langkawi. The total of 190 respondents is used in the study. Descriptive statistical techniques using the method of SPSS software will be used to analyse the responses and research findings in order to draw appropriate conclusion for the survey. The objective of this survey is to measure the level of the respondent's level of satisfaction during their stay at the resort. The level of the measurement is divided into 5 answers which are 1 (best), 2 (good), 3 (no comment), 4 (bad), and 5 (worst). The purpose of these questions is to identify the level of the respondent's satisfaction to the overall vernacular design of the chalet he/she currently stays in the resort. This part of the survey comprises 20 questions as follows:
a) Location (suitability)
k) Entrance signage (chalets)
b) Interior finishes
1) Verandah
c) Circulation
m) Room's price related to the design
d) Size of the chalet
n) Design and layout
e) Ceiling/Roof
o) Toilet
f) Interior view
p) Bathing facilities
g) Artificial lighting
q) Exterior view
h) Accessibility (facilities)
r) Ventilation
i) Amenity (design)
s) Shading devices
j) Chalet reach ability
t) Room's temperature

\section{Analysis of the Survey}

The data is converted to $100 \%$ scale of measurement and is illustrated in graphic charts. The whole result is based on combination of the three selected resorts, and each resort based on answers from the respondents (Table 1). The analysis finds that all respondents give the answers ranging from number 1 to 3 which means they are satisfy with the overall adaptation of vernacular style to the resort design. However, there are several factors should be looked by the architects to the 'no comment' answers by the respondents so that the future design can have better improvements. The 'no comment' answers are as follows:

a) Berjaya Beach Langkawi \& Spa Resort

The following factors have received ' no comment' answers:
i. Interior finishes
vi. Circulation
ii. Ceiling
vii. Artificial lighting
iii. Reach ability
viii. Price
iv. Bathing facilities
ix. Ventilation
v. Temperature
b) Pelangi Beach Resort

X. Size of the chalet

xi. Accessibility

xii. Toilet facilities

xiii. Natural lighting

The following factors have received ' no comment' answers:
i. Interior finishes
vi. Circulation
xi. Size of the chalet
ii. Ceiling
vii. Artificial lighting
xii. Accessibility
iii. Amenities
viii. Price
iv. Bathing facilities
ix. Exterior view
xiii. Toilet facilities
v. Temperature
x. Interior view
xiv. Ventilation
xv. Design Layout

c) Kampung Tok Senik Resort

Only one following factor has received ' no comment' answers:

i. $\quad$ Bathing Facilities

\section{The Average Result}

The average of each of this category is measured as an average of the category ranging from number 1 (positive) to number 5 (negative) answers (Table 2). The average result is computed by SPSS software. The method used is based on 'Compute Variable' as follows: 
i. $\quad$ Compute variable of each resort $=($ Factor $\mathrm{A}+$ Factor $\mathrm{B}+\ldots .)=$. Total $/$ number of factor

ii. Average of the result $=$ Average category of BBR + Average category of PBR + Average category of KTSR $=$ Total 13

The number ranging from category 0 to 1 is regarded as 'best', from category 1 to 2 is regarded as 'good', and from category 2 to 3 is regarded as 'no comment' for answer to the level of satisfaction. There are no answers for the negative categories (category 3-4 and 4-5) in this study. The average result for chalet design at BBR is rated as 2.05 mark ("no comment"), and the total average chalet design is rated as 2.02 mark ("no comment"), and the resort is slightly below 1.94 mark ("good"). The result indicates that PBR has slightly better level of satisfaction than BBR (with only 0.01 difference). KTSR is the only resort in this survey is rated at 1.75 mark which means it is considered as the best resort design with vernacular style compared to BBR and PBR.

\section{Conclusion}

According to Schwanke (1997), traditionally most successful resort projects have been developed around the established resort area.This study is able to indicate several factors based on the analysis towards the improvement of resort design with vernacular style for the future development. The study finds that there is no negative answer obtained in this analysis. This indicates that the overall development of resort architecture in Langkawi does not have any negative responses towards the development of vernacular resort's style. Kampung Tok Senik Resort (KTSR) has the best level of satisfaction compared to Berjaya Beach Resort (BBR) and Pelangi Beach Resort (PBR). The respondents have given positive (below than 2.00 marks) answers for all the questionnaires. KTSR should be used as the model for the future's resort architecture development in Langkawi. Pelangi Beach Resort (PBR) has slightly better level of satisfaction than Berjaya Beach Resort (BBR) (with only 0.01 difference). However, this difference is insignificant and in the resort category both BBR and PBR have a slightly positive (above 2.00 marks) answer.

The study shows that cultural identity and environmental adaptation are significant factors for future success of the resort architecture. Kampung Tok Senik Resort (KTSR) is the best reflected for the model of the development where the regional expression is successfully adopted in the design. In short, the future success of vernacular resort style relies on the improvements of interior finishes, circulation, size of the chalet, ceiling, artificial lighting, accessibility, amenities, room's price, toilet facilities, ventilation, natural lighting, temperature, electrical supply, water supply, services provided, drainage and sewerage, parking, artificial lighting, natural lighting, temperature, natural lighting, artificial lighting, signage, window, door, and furniture. All resorts in this survey have bathing facilities rated as 'no comment'. Adaptation of vernacular style to the design of bathing facilities should become the most significant attention by the architects when designing the resort buildings. There are several important factors co-related to the literature study which should be improved for future success of the resort design with vernacular style. These factors are:

a) Adaptation of vernacular style to the interior finishes, ceiling, toilet facilities, and bathing facilities should be improved as argued by Lawson (1995), that the decoration and furnishing needs to be integrated with the local identity and appearance as well as the needs of durability and easy maintenance services.

b) Accessibility of the resort design should be improved as argued by Schwanke (1997), that the chalet accommodations in resort hotel are often carefully positioned with an attractive setting, frequently offering exceptional view and access to the natural surrounding.

c) The vernacular design of ventilation, natural lighting, and artificial lighting as noted by Lim (1987) and Tan (1994), is that minimal partitions or interior walls of the traditional Malay house, allowing for the flexible use of space, for excellent ventilation, natural lighting, and energy efficient of artificial lighting of the interior. In order to provide full experience of living in a traditional Malay house, these factors should be put into proper consideration for upgrading.

\section{References}

Baud-Bovy, M., \& Lawson, F. (1998). Tourism and recreation handbook of planning and design. Oxford: Reed Educational and Professional Publishing Ltd., (Chapter 2\&4).

Emalgalfta, A., Hassan, A.S., \& Ku Hassan, K.A. (2006). Sustainable housing development in Malaysia: Learning from the resort architecture. Proceeding Papers of International Conference on Sustainable Housing. Penang: School of Housing, Building and Planning, pp. 310-317.

Emalgalfta, A., Hassan, AS., \& Ku Hassan, K.A. (2009). Resort architecture in Langkawi, Malaysia. Penang: Universiti Sains Malaysia Press, (Chapter 3\&4).

Gibbs, P. (1987). Building a Malay house. Singapore: Oxford University Press, (Chapter 3\&7).

Hassan, A. S. (2000). Housing industry: questioning authenticity of Southeast Asian architecture. Journal of Housing, Building and Planning. Penang: Universiti Sains Malaysia Press, 7, 6-12. 
Hassan, A.S., \& Ku Hassan, K.A. (2001). Konsep perumahan tradisional berkelompok dan berdensiti tinggi di pantai barat Semenanjung Malaysia. Penang: Universiti Sains Malaysia Press, (Chapter 3).

Huffadine, M. (2000). Resort design planning, architecture, and interiors. New York: McGraw-Hill, (Chapter 1).

Kamaruddin, M.A. (1983). A vanishing heritage: The old traditional Malay house. Unpublished Master Dissertation. York: University of York, (Chapter 2).

Khan, H. (1991). Houses. MIMAR: Architecture in Development. Singapore: Concept Media Ltd., 39, 26-59.

Ku Hassan, K, A., \& Shuib, N. A. (2000). Architectural setting of beach resort within a rural environment. Journal of Housing, Building Planning. Penang: Universiti Sains Malaysia Press, 7, 34-41.

Lawson, F. (1995). Hotel and resort: Planning design and refurbishment. Oxford: The Architecture Press, (Chapter 2,3,4\&5).

Lim, J. Y. (1984). Under one roof: The traditional Malay house. A World in Cities. Ottawa: IDRC, pp. 15-16.

Lim, J. Y. (1987). The Malay house: Rediscovering Malaysia's indigenous shelter system. Penang: Institut Masyarakat, (Chapter 3).

Mohamed, B. (2002). The development of ecotourism in Malaysia - Is it really sustainable. Proceeding Paper of Regional Conference on Community-Based Ecotourism in Southeast Asia (3-7 March 2002). Chiang Mai, Thailand.

Nasir, A, H., \& Wan Teh, W. H. (1996). The traditional Malay house. Kuala Lumpur: Fajar Bakti Press, 1996. (Chapter 2\&3).

Schwanke, D. et al. (1997). Resort development handbook. Washington D.C.: Urban Land Institute, 1997. (Chapter 2,3\&4).

Smith, D. (1978). Hotel and restaurant design. London: Design Council Publications. (Chapter 2 \& 3).

Steel, J. (2005). Ecological Architecture. London: Thames and Hudson Ltd.. (Chapter 1).

Tan, H. B. (1994). Tropical architecture and interiors. Singapore: Page One Publishing Pte. Ltd. (Chapter 1).

Tan H, B. (2001). Tropical resort: Tourism and resort architecture in South East Asia. Singapore: Page One Publishing Pte. Ltd., (Chapter 1, 8 \& 9).

Tourism Malaysia. (2000). Tourism Malaysia: Langkawi - Malaysia truly Asia. Kuala Lumpur: Minisrey of Tourism, (No Chapter, pp. 8-10). 
Table 1. The results of the survey

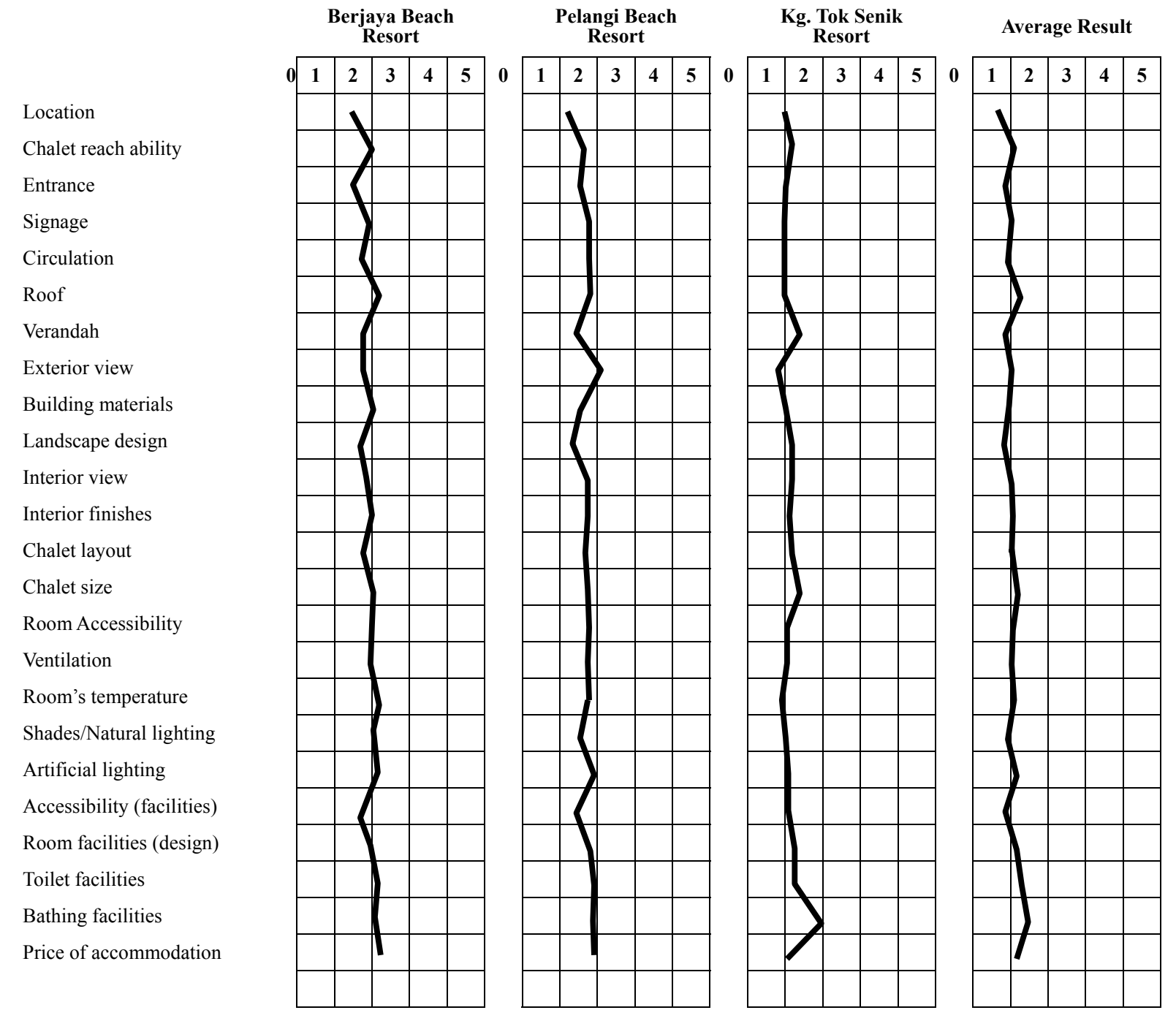

Table 2. The average result of the survey

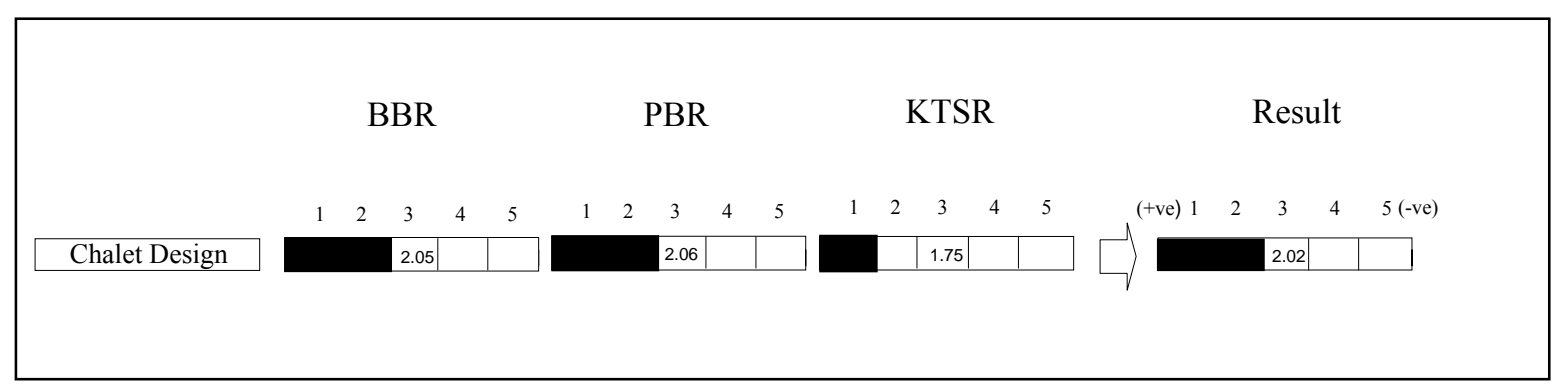



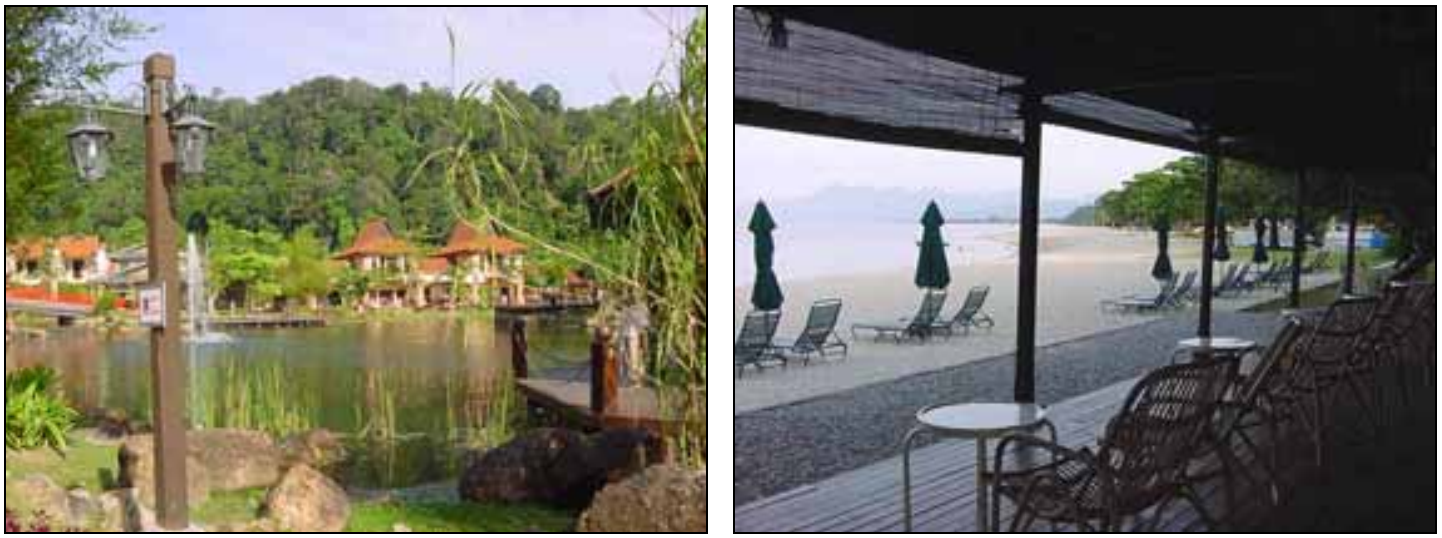

Figure 1. Resort hotels (Oriental Village Langkawi - left photo and The Lanai Resort at Cenang beach - right photo) with attractions of water both as recreational amenity and visual setting
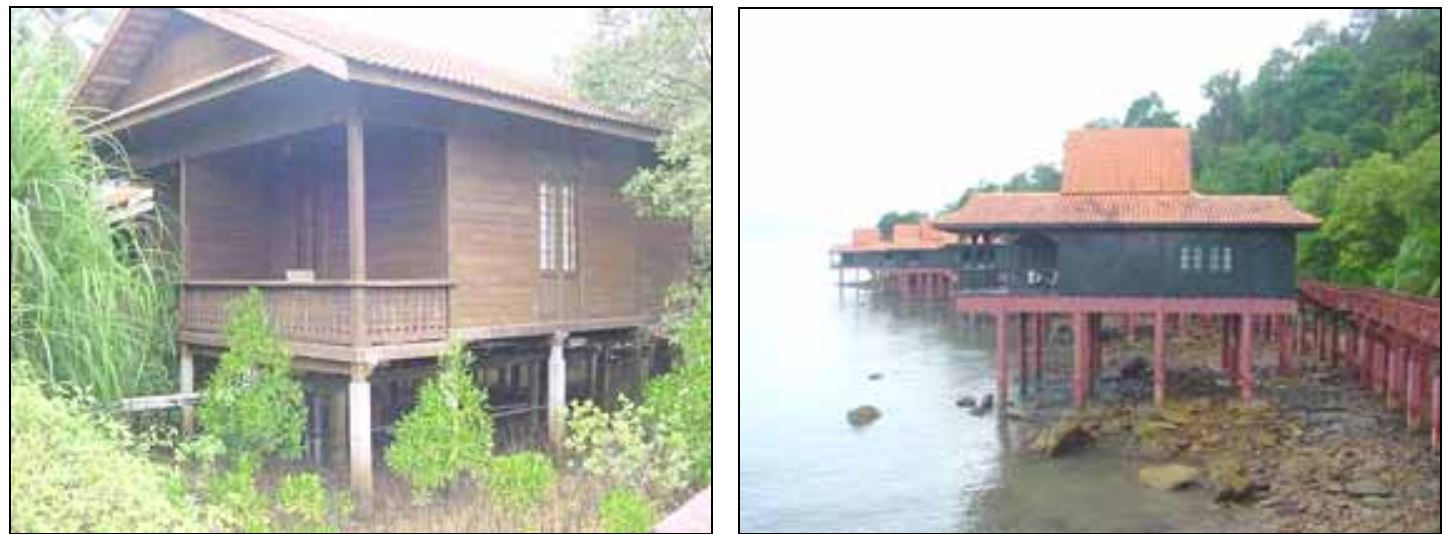

Figure 2. Buai Agro Resort (Left) and Berjaya Beach and Spa Resort (right) located at natural landscape settings
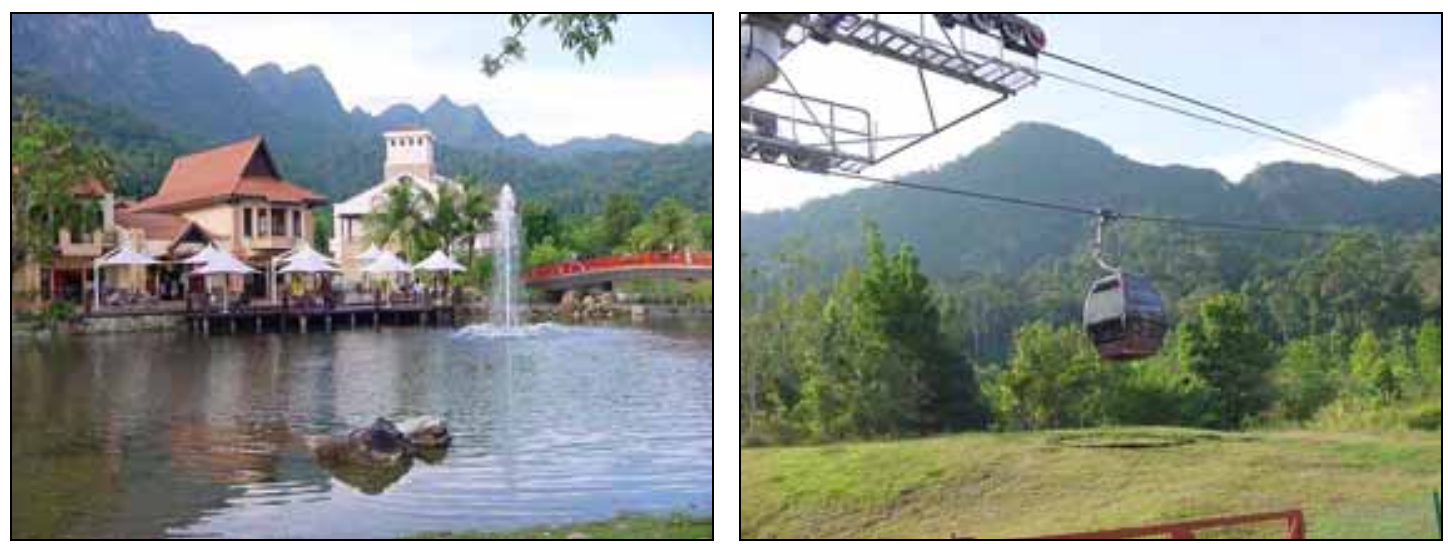

Figure 3. To go to the peak of the majestic Mat Chincang Mount (left photo) the visitors can ride a cable car (right photo) provided at Oriental Village Langkawi 


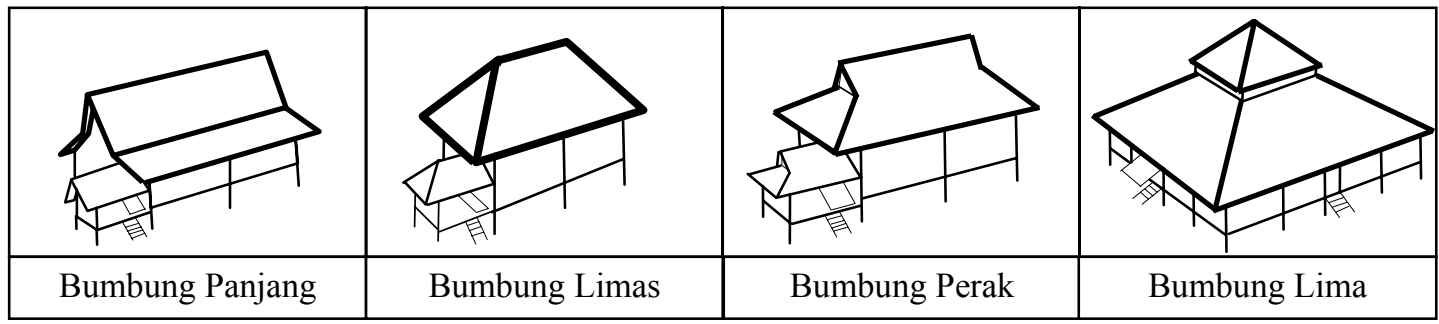

Figure 4. Types of traditional roof form.

Source: Redrawn from the book written by Lim Jee Yuan, 1987

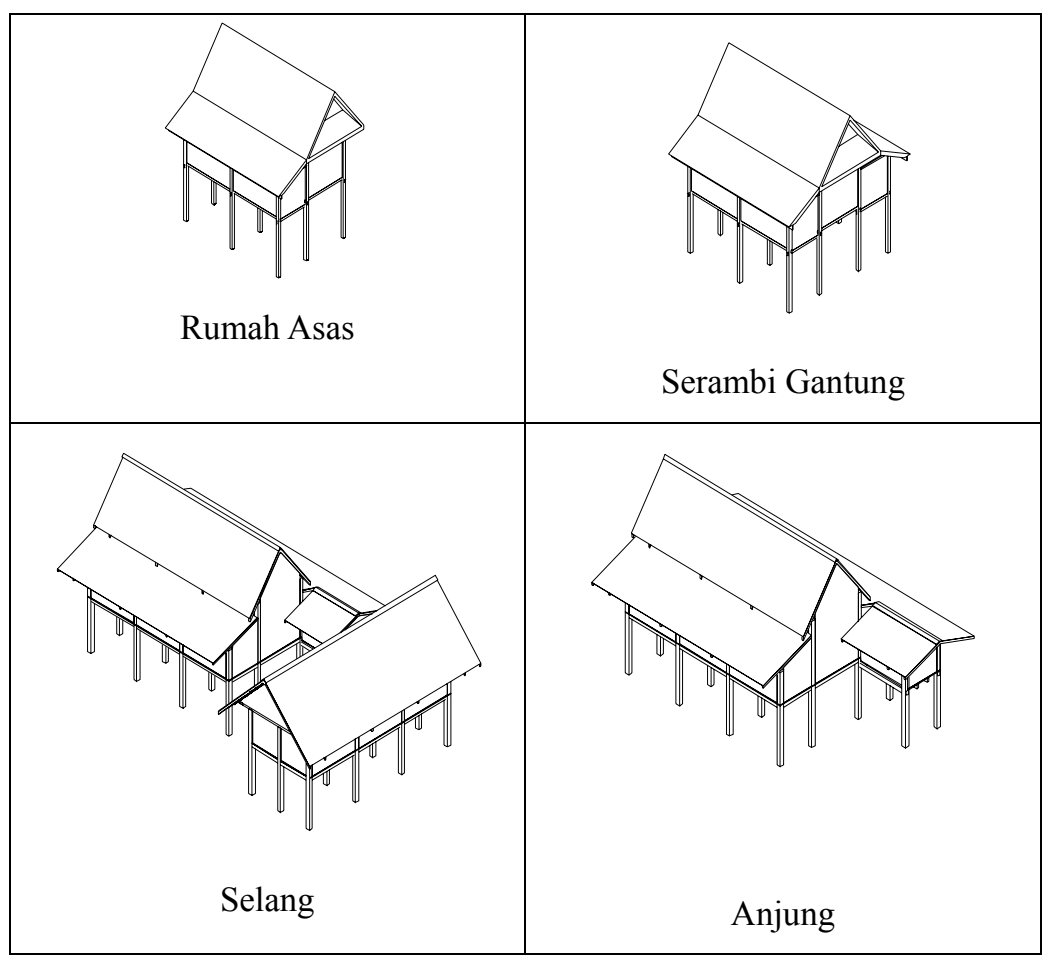

Figure 5. The basic types of house addition for the traditional Malay house

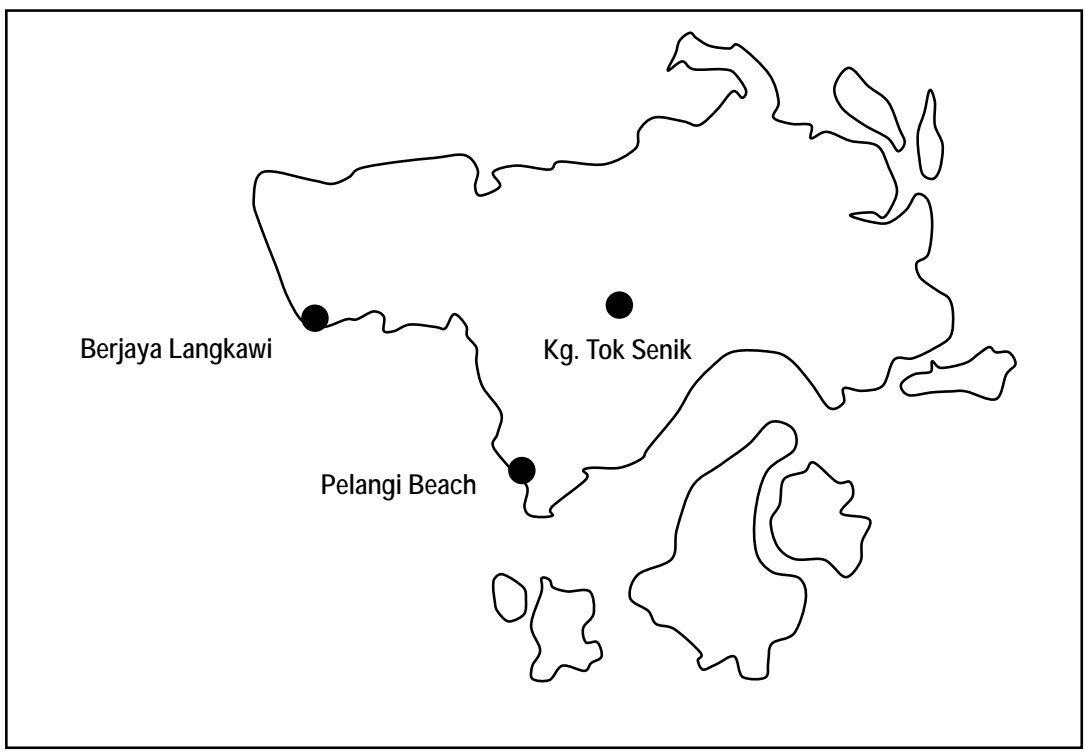

Figure 6. Location of the selected resorts in the case study 

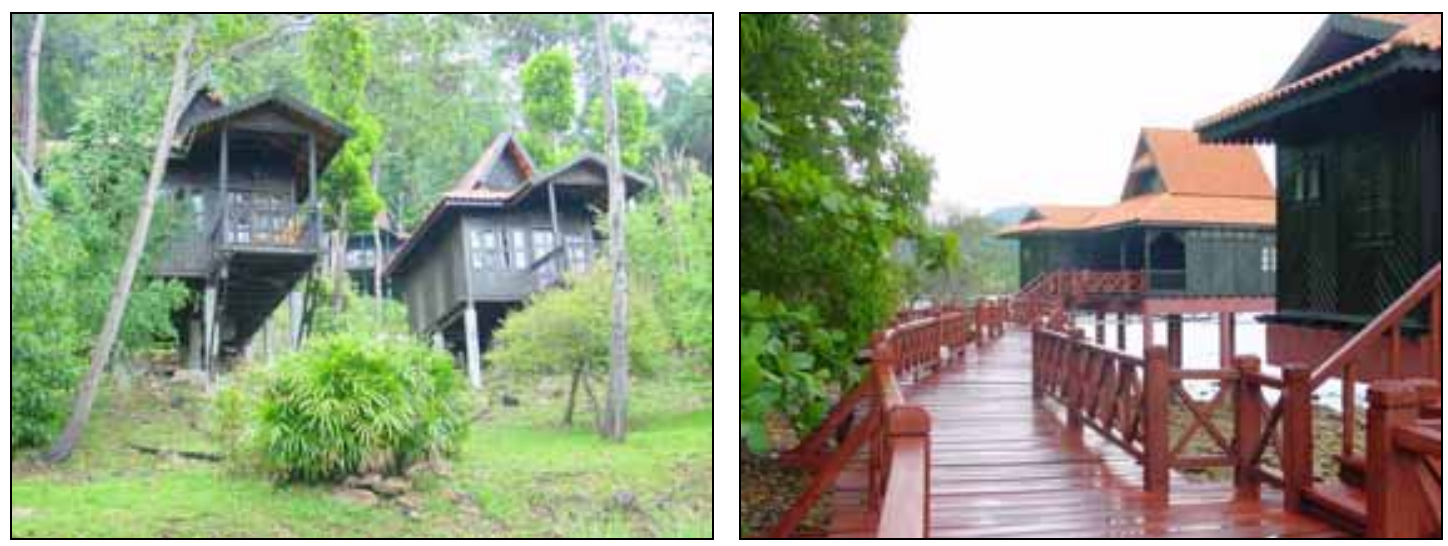

Figure 7. Berjaya Langkawi Beach and Spa Resort at the hill slope (left) and on the sea connected by bridge way (right)
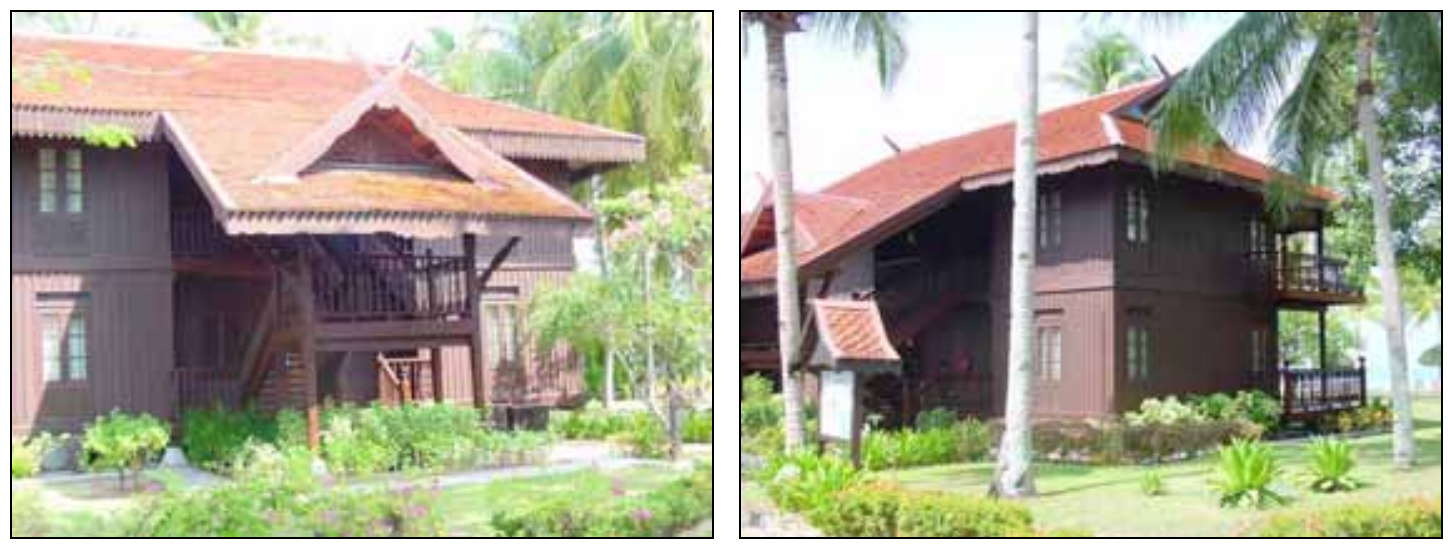

Figure 8. Pelangi Beach Resort
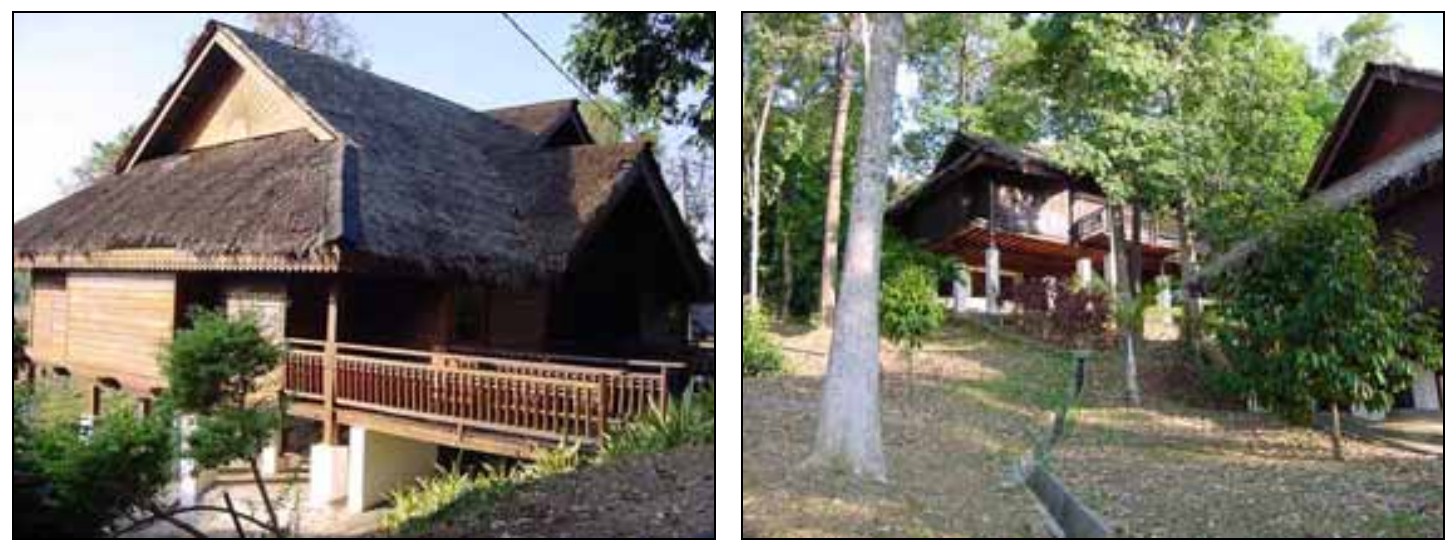

Figure 9. Kampung Tok Senik Resort 